University of California, Hastings College of the Law UC Hastings Scholarship Repository

Faculty Scholarship

2004

\title{
A New Player in the Boardroom: The Emergence of the Independent Directors' Counsel
}

Geoffrey C. Hazard Jr.

UC Hastings College of the Law, hazardg@uchastings.edu

Edward B. Rock

Follow this and additional works at: http://repository.uchastings.edu/faculty_scholarship

\section{Recommended Citation}

Geoffrey C. Hazard Jr. and Edward B. Rock, A New Player in the Boardroom: The Emergence of the Independent Directors' Counsel, 59 Bus. Law. 1389 (2004).

Available at: http://repository.uchastings.edu/faculty_scholarship/932

This Article is brought to you for free and open access by UC Hastings Scholarship Repository. It has been accepted for inclusion in Faculty Scholarship by an authorized administrator of UC Hastings Scholarship Repository. For more information, please contact marcusc@uchastings.edu. 


\section{Faculty Publications \\ UC Hastings College of the Law Library}

Author: Geoffrey C. Hazard, Jr.

Source: Business Lawyer

Citation: 59 Bus. Law. 1389 (2004).

Title: $\quad$ A New Player in the Boardroom: The Emergence of the Independent Directors' Counsel

Originally published in BUSINESS LAWYER. This information or any portion thereof may not be copied or disseminated in any form or by any means or downloaded or stored in an electronic database or retrieval system without the express written consent of the American Bar Association. 


\title{
A New Player in the Boardroom: The Emergence of the Independent Directors' Counsel
}

\author{
By Geoffrey C. Hazard, Jr. and Edward B. Rock*
}

The part-time job of counsel for the occasional special committee of independent directors is about to become a continuing engagement. Over the last thirty years, independent directors have occasionally been represented by independent counsel. Examples include: special litigation committees reviewing derivative suits; independent committees in parent-subsidiary mergers and management buyouts; and internal investigations of misconduct. We predict that with the additional legal requirement imposed on independent directors by the Sarbanes Oxley Act and related changes to SEC rules and Stock Exchange listing requirements, the independent directors, especially those on the Audit Committee, will begin to be represented on a continuing basis by independent legal counsel. Out of this will emerge a new figure in the board room: the Independent Directors' Counsel.

In this Article, we trace the development of counsel for independent directors, identify the forces that are transforming the nature of the engagement, and begin to analyze the promise and pitfalls of adding this new actor in the boardroom, including the implications for corporate law and legal ethics. ${ }^{1}$

\section{EMERGing Role of INDEPENDENT DiRECTORS' COUNSEl}

Over the last thirty years and more, we have seen the emergence of a distinctive role in the boardroom: Counsel for the independent directors. The role has emerged out of the engagement of counsel in several specific contexts for specific tasks. In this section, we review that history.

*Geoffrey C. Hazard, Jr. is Trustee Professor of Law, University of Pennsylvania Law School. Edward B. Rock is the Saul A. Fox Distinguished Professor of Business Law, University of Pennsylvania Law School. This research was supported by the Milton and Miriam Handler Foundation, by the University of Pennsylvania's Institute for Law and Economics, and by the Saul A. Fox Research Endowment. We are grateful for comments and suggestions by Robert Clark, Sean Grifith, Bob Rasmussen, Norman Veasey, and participants at the University of Pennsylvania's Institute for Law and Economics Spring 2004 Corporate Law Roundtable.

1. Jim Cox, working from a different direction, has discussed the possibility of using independent counsel to empower outside directors. James D. Cox, Managing and Monitoring Conflicts of Interest: Empowering the Outside Directors with Independent Counsel, 48 VILL. L. REV. 1077 (2003). 


\section{The Special Litigation Committee in Derivative Suits}

When shareholders seek to sue directors for a breach of fiduciary duty, they typically must do so through a derivative suit, that is, a suit that is brought on behalf of the corporation. The board ordinarily has the ultimate decision over whether the corporation should prosecute litigation. In a derivative suit, a shareholder seeks to displace the board of directors, or more particularly a decision or inaction. As a result, the shareholders' suit is subject to special requirements. In particular, shareholders must assert that the board is unable, unwilling, or incapable of acting.

In corporate law this issue is normally resolved through determination of whether shareholders must make a demand on the board of directors to sue ("demand required") or whether the board is unable to make such a decision ("demand excused"). When demand is required, and the board decides not to pursue an action, that decision will typically be reviewed under the deferential business judgment rule.

Under Delaware law, demand is excused if the shareholder establishes a reasonable doubt that the directors are disinterested and independent, or that the challenged transaction otherwise was not the product of a valid exercise of business judgment. ${ }^{2}$ To meet this requirement, the complaining shareholder must do more than name all the directors as defendants; the complainant must also plead sufficient facts to create a reasonable doubt of board independence in the mind of a Delaware chancellor.

What, then, happens if demand is excused? It was once the rule that when demand was excused, the derivative plaintiff simply prosecuted the claim. Delaware's approach shifted, however, during the 1980s. In the seminal case of Zapata Corp. v. Maldonado, ${ }^{3}$ the Delaware courts took the view that the board's lack of independence that led to excusing demand was not necessarily permanent or irreversibly disabling. In particular, if the board established a special committee of uninvolved directors (typically newly appointed ones), and delegated the decision whether to proceed with the litigation to that committee, then the committee could assume the authority of the board, and reassert control over the litigation. ${ }^{4}$ That has become the established practice not only in Delaware but in other jurisdictions as well. ${ }^{5}$

In order for the directors to reassert control through the special committee and prevail on a motion to terminate the litigation, the burden is on the special litigation committee ("SLC") to convince the court that "(1) its members were independent; (2) that they acted in good faith; and (3) that they had reasonable

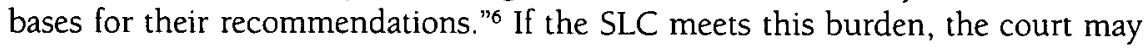

2. Aronson v. Lewis, 473 A.2d 805 (Del. 1984).

3. 430 A.2d 779 (Del. 1981).

4. Id. at 785 .

5. See Auerbach v. Bennett, 393 N.E.2d 994 (N.Y. 1979).

6. In re Oracle Corp. Derivative Litig., 824 A.2d 917, 928 (Del. Ch. 2003) (citing Zapata, 430 A.2d at 788-89); Katell v. Morgan Stanley Group, Civ. A. No. 12343, 1995 WL 376952, at *6 (Del. Ch. June 15,1995$)$. 
grant the committee's motion or, in its discretion, permit the litigation to proceed if, in its "judicial business judgment," it concludes that proceeding is in the best interests of the company. ${ }^{7}$

One key factor in a SLC's ability to meet its burden is the retention of genuinely independent counsel to guide the SLC through its obligations and to aid in the evaluation of the merits of the underlying claim. To maximize the likelihood that an SLC's recommendation to terminate the litigation will be respected, the SLC is well advised to retain counsel with no prior relationship with the company. ${ }^{8}$ Retaining such counsel has become standard practice.

\section{Special Committees in the MBO and Parent-Subsidiary MERGER CONTEXTS}

A second context for appointing special counsel is a management buyout ("MBO") or a parent-subsidiary merger. Both transactions raise obvious conflicts of interest on the part of management. In each case, the would-be acquirer (management or the parent) would like to acquire the remaining shares at the lowest possible price, while also owing a duty to the company to pay fair value. Various protocols and bright line rules have been proposed-such as per se prohibition on "going private" transactions. ${ }^{9}$ The practice that has emerged, however, has been much more nuanced. ${ }^{10}$

In both contexts, the developing Delaware jurisprudence encourages (although does not mandate) the use of a substantively independent, active, and effective committee of independent directors to represent the interests of the noncontrolling shareholders. The effect of such a committee-and thus the inducement to create one-is to shift litigation burdens from the conflicted fiduciary (management or the controlling shareholder) to the non-controlling shareholders. The shift typically is that of the burden of proof. In some cases, the use of a special committee can also shift of the standard of review from "entire fairness" to business judgment rule. ${ }^{11}$

For use of such a special committee to have this effect, the committee must be shown to be active and independent, and not merely "formally" so. This independence depends, in significant measure, on whether the committee hires independent advisers-counsel independent of the management or parent company

7. Zapata, 430 A.2d at 789 . In Zapata, the Delaware Supreme Court held that the burden that the committee must meet on each issue is "akin" to that on summary judgment. Id. at 788.

8. For an example of a case where the court rejected the recommendation to terminate an action, despite the presence of a genuinely independent counsel, see Oracle, 824 A.2d at 917.

9. See, e.g., Victor Brudney \& Marvin A. Chirelstein, A Restatement of Corporate Freezeouts, 87 YALE L. J. 1354 (1975) (proposing a prohibition on management buyouts).

10. See Edward B. Rock, Saints and Sinners: How does Delaware Corporate Law Work?, 44 UCLA L. REV. 1009 (1997).

11. When the transaction is between a controlling shareholder and the firm, the standard is always entire fairness; when the transaction is between a director and the firm, the use of a genuinely independent special committee can shift both the burden (to the challenging shareholders) as well as the standard (from entire fairness to business judgment rule). Kahn v. Tremont Corp., 694 A.2d 422, 428-29 (Del. 1997). 
and investment bankers who can advise on valuation. In the jurisprudence that has developed, the performance of counsel for the committee has been viewed as particularly important. For example, in Kahn $v$. Tremont,${ }^{12}$ the fact that the special committee chose counsel who were recommended by, and had previously worked for, the parent company was a factor in the court's conclusion that the special committee was not independent. ${ }^{13}$

\section{INDEPENDENT COUNSEL IN INTERNAL INVESTIGATIONS}

Independent directors have also retained independent counsel for internal investigations. When a company launches an internal investigation in the wake of a scandal, the credibility of the investigation depends in no small measure on the perception that the law firm conducting the investigation is independent of the potential wrong doers. To take but one example, when Enron launched an investigation of accounting irregularities, it appointed a special committee of directors, who in turn retained special outside legal counsel, which was largely (although not totally) independent of Enron. ${ }^{14}$

\section{OTHER CONTEXTS}

The scandals at Enron and elsewhere have led to pervading suspicion of business management, particularly where top level managers stand to realize unusual personal gain from their corporate positions. Current topics of concern include the proper level of executive compensation and transactions of executives with related entities. It is a fair prediction that the employment of special board committees comprised of independent directors will find wider uses. And the special committees will typically require special counsel.

\section{The Big Bang: SARBanes-OxLey AND the Stock EXCHANGE RULES}

As described above, the retention of independent outside counsel for independent directors is not a new development. Indeed, it has become routine on a transaction-specific or engagement-specific basis. Currently, corporate management would be ill advised to attempt a parent-subsidiary merger or a management buyout without establishing a special committee of independent directors who are assisted by genuinely independent counsel. Similarly, one would not sensibly incur the costs of establishing a special litigation committee to evaluate derivative litigation without ensuring that the committee hired independent outside counsel. It would simply be a waste.

12. Id.

13. Id. at $428-30$.

14. In the five years previous, counsel for the special committee, Wilmer, Cutler \& Pickering, had represented in matters unrelated to the transactions at issue, specifically, an Enron subsidiary before the U.S. Supreme Court, and in a merger proceeding in the EU. William Powers, Report to the Board of Directors of the Enron Corporation, Feb. 1, 2002 ("Powers Report") at fn. 4 (on file with the authors), available at http://news.findlaw.com/wp/docs/enron/specinv020102rpt 1.pdf. 
Sarbanes-Oxley ("SOX") 15 is important not because it invents the role of independent director, but because it makes a variety of corporate functions mandatory and vastly increases their legal complexity, and consequently enhances the requirements of corporate judgment that can withstand question or challenge. We assert that this complexity will lead to an expansion of lawyers' roles.

SOX changes the regulatory landscape for publicly traded corporations in two principal ways: It does so directly through new process requirements; and it does so indirectly through changes in the stock exchanges' listing agreements that were encouraged by the SEC in its supervisory role over self regulatory organizations. ("Encouraged" is an understatement).

Once SOX, the SEC rules, and the changes in the stock exchange listing requirements take full effect, the institution of the board will be fundamentally changed if not transformed.

The most significant change is with regard to the Audit Committee. Under the new regime:

- The Audit Committee of a corporation subject to the new regime will be comprised solely of independent directors. ${ }^{16}$ Moreover, the company must disclose whether at least one of the members of the Audit Committee is a "financial expert" and if not, why not. ${ }^{17}$

- The Audit Committee statutorily will be "directly responsible for the appointment, compensation, and oversight of the work of any registered public accounting firm employed by that issuer (including resolution of disagreements between management and the auditor regarding financial reporting) for the purpose of preparing or issuing an audit report or related work, and each such registered public accounting firm shall report directly to the audit committee."18

- The Audit Committee will have to "establish procedures for- $(A)$ the receipt, retention, and treatment of complaints received by the issuer regarding accounting, internal accounting controls, or auditing matters; and (B) the confidential, anonymous submission by employees of the issuer of concerns regarding questionable accounting or auditing matters." ${ }^{19}$

- The Audit Committee will have to pre-approve audit and permissible nonaudit services. ${ }^{20}$

- The Audit Committee must have a "charter that addresses a list" of specified duties, responsibilities and purposes, one of which must be to "assist board

15. Sarbanes Oxley Act of 2002, Pub L. No. 107-204, 116 Stat. 745 (2002) (codified in scattered sections of 11, 15, 18, 28, and 29 U.S.C.) [hereinafter Sarbanes-Oxley Act].

16. Sarbanes Oxley Act, Pub L. No. 107-204, §301, 116 Stat. 745, 775 (2002) (amending 15 U.S.C. $\$ 78 f)$.

17. Id. $\S 407$ (codified at 15 U.S.C. $\S 7265$ ).

18. Id. $\S 301(2)$.

19. Id. §301(4).

20. Id. $\S 202$ (amending 15 U.S.C. $\S 78 j-1$ ). 
oversight of (1) the integrity of the company's financial statements [and]

(2) the company's compliance with legal and regulatory requirements. . ." "21

- Part of the Audit Committee's responsibility is to monitor and ensure that the audit engagement team not overstay its permissible term. The term limit is five years on, five years off for the audit partner, and no member of the audit team may accept a financial reporting job with the issuer without first observing a one year cooling off period. ${ }^{22}$

- The Audit Committee must also monitor audit partner compensation to ensure that the audit partner does not get paid based on non-audit services provided to the issuer.

- The Audit Committee will have the authority to engage independent counsel and other advisers it deems necessary, at company expense. ${ }^{23}$

In addition to these prescribed responsibilities, additional duties devolve on the Audit Committee as derivative from the increased obligations on other actors. Thus, for example, the CEO and CFO must certify that they have disclosed to the Audit Committee "(A) all significant deficiencies in the design or operation of internal controls which could adversely affect the issuer's ability to record, process, summarize, and report financial data and ... (B) any fraud, whether or not material, that involves management or other employees who have a significant role in the issuer's internal controls." ${ }^{24}$ When such disclosures are made, the Audit Committee, as the prime decision maker with regard to accounting functions, will presumably be obliged to act. ${ }^{25}$

Similarly, section 307 of SOX requires attorneys to report "up-the-ladder" evidence of securities law or fiduciary duty violations by the company or its agents. ${ }^{26}$ In the first instance, the attorney should report to the chief legal counsel or the CEO. If the counsel or the officer does not respond appropriately, the attorney must then report the evidence to the Audit Committee or to another committee comprised entirely of independent directors, such as a "qualified legal compliance committee." ${ }^{27}$ As before, the Audit Committee presumably has an obligation to act once it has received such a report.

As one commentator has noted, the new responsibilities of the Audit Committee "may require the audit committee to be in regular, sometimes continuous, communication with the outside auditors, and members may expect the committee to be at times as a practical matter in continuous session." ${ }^{\text {28 }}$

21. New York Stock Exchange, Listed Company Manual, §303A.07(b)(i)(A), available at http:// www.nyse.com [hereinafter NYSE Listed Company Manuall; Bart Schwartz and Jonathan Freedman, Corporate Counsel: Accounting Scandals, the New Rules and Board Culture, 228 N.Y. L.J., Oct. 10, 2002, at 5 .

22. Sarbanes-Oxley Act $\$ 203$ (amending 15 U.S.C. $\$ 78 j-1$ ).

23. Id. $\S \S 301(5),(6)$.

24. Id. $\S 302(\mathrm{a})(5)(\mathrm{A})-(\mathrm{B})$ (codified as 15 U.S.C. $\S 7241$ ).

25. Peter M. Collins, Outside Counsel: Sarbanes-Oxley Act Creates a New Role for the Audit Committee, 228 N.Y. L.J., Oct. 17, 2002, at 4 [hereinafter Collins].

26. Sarbanes-Oxley Act $\S 307$ (codified as 15 U.S.C. $\S 7245$ ).

27. Id.

28. Collins, supra note 25 , at 4 . 
Microsoft's most recent proxy statement provides a dramatic illustration of the sheer magnitude of the Audit Committee's responsibilities. The last three pages contain the "Audit Committee Responsibilities Calendar" with thirty-two separate entries. ${ }^{29}$

SOX's changes to the Audit Committee are the most far reaching. However, the other main board committees-the Nominating and Compensation committeeswill also be transformed. Like the Audit Committee, they must be staffed by independent directors. ${ }^{30}$

Finally, non-management directors will be required to meet regularly without management. ${ }^{31}$

We close this section with a brief thought experiment. For your sins, or perhaps because you are a glutton for punishment, or just want to do the right thing, you have agreed to become a member of the Audit Committee of a publicly held corporation. Perhaps, because you have a lot of time on your hands, you have agreed to sit on the Compensation or Nominating Committee as well. You very much want to do the right thing. You have reviewed the duties that have been imposed on independent directors of publicly held firms. You are aware of the various roles that independent counsel has played in the past. You know that SOX mandates that the Audit Committee have the authority to retain independent counsel at company expense. You also want to be able to get director liability coverage. You suspect that "[i]nsurance carriers who write directors' liability policies may be expected to consider measures encouraging their audit committee insureds to undertake proactive self-defense measures, including careful memorialization of their endeavors and engagement of the independent counsel and advisers contemplated in Section $301(\mathrm{~m})(5) . "{ }^{32}$ Can you seriously imagine not retaining independent counsel at least for the Audit Committee, given that it looks like that committee may, as a practical matter, be in continuous session?

Or run the thought experiment slightly differently. Suppose that a CEO or the chair of the Nominating Committee is recruiting someone to join the board and to chair the Audit Committee. The potential director indicates interest but, prior to agreeing, asks that the Audit Committee be provided with its own, independent, counsel. ${ }^{33}$ Can the CEO or the Nominating Committee chair refuse the request? If the request is turned down, what signal will it send?

\section{Reaching the Tipping Point: From Transaction REPRESENTATION TO ONGOING ROLE}

We make a prediction. Some independent directors, especially those who serve on an Audit Committee, will conclude that they are better off with independent counsel appointed on a standing basis. Their special counsel will be available to

29. Microsoft, 2003 Proxy Statement at 26-28 (Sept. 29, 2003).

30. NYSE Listed Company Manual, supra note $21, \S 303 \mathrm{~A} .04$.

31. Id. § 303A.03.

32. Collins, supra note 25 , at 4 .

33. We owe this version of the thought experiment to Jim Agger. 
guide them through the complexities of the new structure, and be up to speed if anything untoward should happen (like an employee reporting misconduct to the Audit Committee). Once an independent lawyer is hired for the Audit Committee, that lawyer will, over time, become the counsel for the independent directors more generally; he will guide them through their obligations on the Compensation Committee, the Nominating Committee, and in their SOX mandated separate meetings. Within a few years, we will become familiar with a new figure in the boardroom, the Independent Directors' Counsel, or "IDC."

This conclusion is impelled by several considerations. As the previous survey suggests, the amount of legal counseling generated by the Audit Committee in particular, and the independent directors in general, has reached a level where directors will seek special counsel and lawyers will specialize in providing such counsel. ${ }^{34}$

Once this threshold is passed, the question becomes whether Audit Committee members will prefer to be counseled by the company's in-house general counsel (when there is one), the company's main outside law firm, or prefer an independent lawyer. As noted earlier, SOX mandates that the Audit Committee have the option of retaining independent counsel at company expense. The new regulations accentuate the differences in, and therefore the potential conflicts between, the roles of managers and independent directors that have always been present. The Audit Committee function, under the new system, is almost explicitly adversarial. The Compensation Committee, while less heavily regulated, faces conflicts of interest when setting the CEO's compensation. The Nominating Committee in nominating directors must exhibit independence. Finally, the board as a whole, in making the decision to retain or terminate the CEO, similarly can find itself with interests adverse to the current management team. With these conflicting interests, retaining the IDC from an independent firm is not merely reasonable but virtually imperative. The Audit Committee at Time Warner, for example, has its own outside counsel. ${ }^{35}$

Second, SOX's redefinition of the role of board committees sharpens the conflicts of interest between managers and independent directors inherent in a monitoring model of the board of directors. In particular, the extent to which SOX seeks to implement a "judgmental monitoring model" of board governance in which outside directors are expected to keep a sharply skeptical eye on managers, puts pressure on the existing relationships. Thus, for example, in the check list of Audit Committee activities in Microsoft's 2003 Proxy Statement, the Audit Committee is expected to:

Review policies and procedures with respect to transactions between the Company and officers and directors, or affiliates of officers or directors, or transactions that are not a normal part of the Company's business ... [c]onsider and review with Finance management and the General Auditor:

(a) Significant findings during the year and management's responses thereto[;]

34. Indeed, lawyers post-SOX have already started marketing themselves in this way.

35. Time Warner, 2004 Proxy Statement at 19 (Apr. 1, 2004). 
(b) Any difficulties encountered in the course of their audits, including any restrictions on the scope of their work or access to required information[;]

(c) Any changes required in planned scope of their audit plan. ${ }^{36}$

Similarly, the Audit Committee is expected to:

Meet with the independent auditor in executive session to discuss any matters that the Committee or the independent auditor believes should be discussed privately with the Audit Committee[;] Meet with the General Auditor in executive session to discuss any matters that the Committee or the General Auditor believes should be discussed privately with the Audit Committee. ${ }^{37}$

This sort of "judgmental monitoring" contains inherent tensions between managers and directors. Consider, for example, the question of transactions between the company and its officers against the background of Enron or Adelphia. In those, perhaps pathological, cases, outside directors might well have been better served by genuinely independent counsel. In light of those experiences, some directors might plausibly conclude that separate counsel would be useful.

Third, the liability implications of SOX are unclear and will only be worked out over the coming years. ${ }^{38}$ Given this legal uncertainty, some Audit Committees may plausibly conclude that they should have their own counsel as a form of insurance against being second guessed down the line. Similarly, separate from liability concerns, directors have strong stakes in their reputations. Given the outcry over the last couple of years, some Audit Committees may plausibly conclude that they should have their own counsel.

Finally, depending on the liability implications of SOX, the insurance companies that issue directors and officers liability insurance may take the position that Audit Committees ought to have their own independent counsel. If it becomes a condition of insurance (which it is not currently), then Audit Committees will immediately retain independent counsel.

The spread of an IDC would go against the grain of contemporary corporate culture, but it is not necessarily bad. Separating the lawyers' roles by retaining an IDC may even be necessary to preserve productive team work. The complexity and variety of the different roles played by lawyers in a post-SOX board room and executive suite are so varied and conflicting that unless the roles are differentiated, the general counsel may be unable to fulfill his duties to the independent directors and also be a member of the management team. SOX has not created these conflicts; it has merely highlighted and intensified them. How can the lawyer who is advising the management team on the legal aspects of acquisitions also be

36. Microsoft 2003 Proxy Statement, supra note 29, Audit Committee Responsibilities Calendar at items 22 and 23.

37. Id at items 30,31

38. William B. Chandler III \& Leo E. Strine, Jr., The New Federalism of the American Corporate Governance System: Preliminary Reflections of Two Residents of One Small State, 152 U. PA. L. REV. 953, 981-87 (2003). 
advising the compensation committee on management compensation and advising the Audit Committee on its oversight functions?

\section{THE IDC: EMERGING ROLE AND IMPLICATIONS}

Suppose that we are right and that a not insignificant number of firms end up hiring IDC to represent the independent directors. How will this change the corporate world? What sorts of problems are likely to emerge? In the first subsection, we will look at potential benefits. In the second, we will examine problems.

\section{Transforming the Teamwork Model In the BoARd RoOM?}

One fairly explicit goal of SOX is to transform the boardroom. We take no position on whether this is a good thing or a bad thing (or even on what would count as a change). Rather, in this subsection, we are interested in how the emergence of an IDC will affect boardroom decision-making, and how these new institutional structures will fit with existing understandings of the lawyer's role.

\section{From Status Quo to New Frontier}

The traditional model of corporate governance has been of a harmonious board advising a CEO who is both chairman of the board and president of the company. The CEO sets company policy, selects and directs the staff (including legal counsel both inside and outside), nominates the directors, and frames the board agendas. The agendas are routinely approved on the basis of discussion limited to explication of management purposes and premises, and without dissent. A board member with differences or reservations voices them quietly and then, if dissatisfied, resigns. More typically, he simply declines re-nomination in the annual election of directors.

The concept governing the relationship is "team." "Teamwork" implies the absence of overt dissent from board members, staff members, or outside consultants, particularly the accountants and lawyers. In the traditional model, achieving top level management status is highly competitive but positions are generally secure after arrival. Corrective pressure comes from outside, in the form of the competition, the regulatory authorities, and decline of the company's stock price. Occasionally, sometimes more often, advice is sought from outside consulting firms. Even then, there is usually no dissent at the top, inasmuch as outside consulting firms typically made findings and recommendations that had been anticipated if not scripted by management. ${ }^{39}$

39. The level of internal harmony contrasted with the mood in other arenas of discourse, where debate was open and sometimes rancorous: Relations with organized labor; with federal regulatory agencies and sometimes those at the state level; in politics (particularly after the New Deal and its Democratic successors); and some sectors of academia. In some local business communities a more contentious style was accepted, for example, in Texas and Hollywood. However, the contentious climates in these other arenas, if anything, reinforced the model of quiet consensus that prevailed in predominant business circles. 
This traditional model has been under pressure from many directions and for many years. Since the beginning of the 1980s, takeovers-hostile, quasi-hostile and friendly-have posed a threat to the status quo. Institutional investors have become more active. Boards have become more independent. One measure of the extent of the transformation is that CEO tenure has steadily declined. ${ }^{40}$

In combination with existing trends, the emergence of the IDC may spark further evolution. ${ }^{41}$ With the presence of the IDC, the model of the boardroom may shift from "team work" in which differences of agreement are submerged and resolved outside the board room to a more open board room discussion in which board meetings become less ceremonial and more frank, even contentious, and in which competing views are presented and resolved.

\section{The New Board and the Old Rules}

A new board reality would put pressure on the existing approaches to representation. Under the traditional model, lawyers, those both in inside legal departments and in outside firms, were expected to conform to the teamwork ideal. The securities laws and evolving common law liability rules reinforced the model. Lawyers were gatekeepers against illegal misconduct and evidence of such misconduct. Overt dissent over legal and accounting issues would create evidence that, through adverse discovery, could be devastating in later litigation.

Rule 1.13 of the American Bar Association Rules of Professional Conduct can be interpreted in light of the teamwork model of intra-corporate relationships. The underlying themes in Rule 1.13 for relations between legal counsel and a corporate client are caution, consultation, and subordination. The key terms concern the objective to be pursued, the information on which a lawyer's intervention may be based, and the procedures to be adopted when action is appropriate.

The objective of the lawyer's function in corporate representation is defined in Rule 1.13 as serving the "best interest of the organization." 42 This is an entirely

40. Marcel Kahan \& Edward B. Rock, How I Learned to Stop Worrying and Love the Pill: Adaptive Responses to Takeover Law, 69 U. CHi. L. REv. 871, 883 n.58 (2002) (citing Tom Neff \& Dayton Ogden, Anatomy of a CEO, CHIEF EXECUTIVE, Feb. 2001, at 30, 31 (reporting that median tenure of CEOs in office declined from seven years in 1980 to five years in 2000); Mark R. Huson et al., Internal Monitoring Mechanisms and CEO Turnover: A Long Term Perspective 56 J. FIN. 2265 (2001), available at http:// www.ceogo.com/CEODEPARTURES/CEOTURNOVER/ (finding an increase in forced CEO turnover in the 1971 to 1994 period); Denis B.K. Lyons, CEO Casualties: A Battlefront Report, DIRECTORS \& BOARDS, Summer 1999, at 43 (reporting that the percentage of Fortune 100 companies with CEOs with tenure of five years or less increased from forty-six percent in 1980 to fifty-eight percent in 1998); CEO Turnover Up, SF BUS. TIMES, July 6, 2001, available at http://sanfrancisco.bizjournals.com/san francisco/stories/2001/07/02/daily32.html (last visited Mar. 29, 2002) (reporting increase in turnover in Fortune 1000 companies); Drake Beam Morin, CEO Turnover and Job Security 8 (Special Report 2000) (finding "increased turnover and job loss at the highest corporate level" in an international study).

41. We do not claim that SOX-induced changes will be the proximate cause of a change in the model of board governance. Many other factors come into play, with legal change being only one of them. If SOX is the catalyst for significant change, it will likely be because of a general acknowledgement that a less consensual boardroom may be appropriate, at least for some companies some of the time. Our point is that for those companies that shift their governance structure, the IDC is likely to play a critical role.

42. Model Rules of Prof'l Conduct R. 1.13 (2000). 
appropriate definition but a different one can be imagined. The lawyer's function could have been defined in stricter "gatekeeper" terms, for example "assuring compliance with legal requirements." The "best interest" standard is more ambiguous and hence less imperative. The standard of information specified in Rule 1.13 as a basis of action is that of knowledge, whereas a more skeptical level could have been specified such as "reason to believe" or suspicion. The appropriate responsive action is framed in terms of reconsideration, review, and resort to higher corporate authority.

Moreover, these prescribed responses in fact presupposed that the lawyer who confronts a problematic situation typically will be a member of a multi-member law department or outside law firm, not a solo. In that context, ordinarily it would be a junior lawyer who first encounters troublesome facts, but a senior lawyer who would decide what to do. The transmission between them would itself require time, consultation, and deliberation. The decision about action would be made by the senior, who would be fully mindful of the "team" ethos.

In academic discussion of the corporate lawyer's responsibilities under Rule 1.13 , a standard hypothetical concerned a young lawyer discovering that operatives in the engineering department were about to poison a city's reservoir, the issue then being whether the lawyer could "go to the authorities." It is, however, a virtual certainty that no such scenario would occur in real life. Rather, in the bureaucratized world of today the sequence would be much less dramatic: The young lawyer might discover that the engineering department was not properly documenting its water-purity certifications. Appropriate response to that situation certainly would not involve going anywhere outside the corporate structure. Almost certainly, it would not include pushing the matter all the way up to the corporation's board of directors.

It is of course impossible to establish whether the cautious approach to the corporate lawyer's responsibilities in Rule 1.13 has properly served legitimate corporate interests in the long run. In our estimate, those interests have been adequately served by the rule as it stands. Or at least a more stringent standard would not on balance have better served long run corporate interests. Most corporate officials are honest and try to obey the law and are encouraged to consult legal counsel. At the same time, there is no way to compel a recalcitrant corporate official to consult a lawyer, or to prevent concealment of illegal machinations by management or high level employees from the legal department. Tycoons can compartmentalize their legal work among different firms, clever but corrupt bookkeepers can conceal embezzlements for a long time.

The emergence of the IDC potentially shifts the balance with respect to the lawyers' roles. A useful framework for analyzing this prospect is the "Cheek Report," the now-common term for the Report of the American Bar Association Task Force on Corporate Responsibility. ${ }^{43}$ The stature of the Report is suggested by reference to the composition of the Task Force: Top level corporate lawyers and

43. Report of the American Bar Association Task Force on Corporate Responsibility (Mar. 31, 2003) [hereinafter Final Report]. 
academics headed by James Cheek, long associated with the Legal Advisory Committee of the New York Stock Exchange.

The Cheek Report made many important recommendations addressed to corporate governance, particularly the roles of independent directors and of corporate counsel. Concerning corporate counsel, the Report recommended revision of the ABA Model Rules of Professional Conduct, specifically Rule 1.6 (governing the scope of permissible "whistle-blowing") and Rule 1.13 (governing corporate counsel's responsibilities to the organization).$^{44}$ Concerning independent directors, it recommended much greater autonomy through several specific changes, addressed below. ${ }^{45}$ But the Report did not proceed to what seems to us the necessary conclusion-that the independent directors of a public company have their own legal counsel.

In fact there were two Cheek Reports, a Preliminary Report, July 16, 2002, and the final Report issued nine months later. The Preliminary Report proposed enhanced autonomy for the independent directors, as follows:

- A "substantial majority" of the board should be independent;

- A board committee constituted of independent directors charged with nominating successor independent directors;

- Audit and Compensation Committees constituted of independent directors;

- A corporate governance committee constituted of independent directors and charged with general authority over regulatory compliance, and authorized to retain independent counsel;

- Some committee of independent directors to review transactions involving directors or executive officers of the company;

- Some committee of independent directors to have regular private meetings with general counsel. ${ }^{46}$

These proposals were carried forward and elaborated in the Final Report.

The Preliminary Report recommended changes in Rule 1.13 that would encourage corporate counsel to take action when confronting serious management misconduct. ${ }^{47}$ Regarding Rule 1.13 as it stands, the Preliminary Report stated: "The Task Force believes that this [text of present Rule 1.13] unduly emphasizes the avoidance of 'disruption' of the organization while playing down the more important goal of minimizing harm resulting from the misconduct." 48

It will be appreciated that there is a correspondence between the term "team play" (describing the proper role of corporate counsel in the old regime) and the term "disruption" (in Rule 1.13, describing what is to be avoided if possible). "Disruption" is violation of "team play." The Final Report accordingly recom-

44. Id. at $34-35$.

45. Id. at 62 .

46. Preliminary Report of the American Bar Association Task Force on Corporate Responsibility (July 16, 2002), at 17-21.

47. Id. at 27 .

48. Id. at 28 (emphasis in original). 
mended several specific changes in Rule 1.13 to shift the emphasis in the direction of protecting the company.

So far so good. But the Final Report has an interesting footnote, number 54. The footnote annotates the following statement:

[L]awyers must ... retain ... professional detachment . . . even at the risk of being perceived as ... obstructive of the business plans sought by the corporation's executive officers. There are times ... when the corporate lawyer must ... assure that the corporate client retains other counsel who can exercise the requisite professional detachment. ${ }^{49}$

Footnote 54 then says:

It has been suggested that such considerations warrant, as a matter of regular practice, the retention of counsel other than general corporate counsel to advise the board of directors or one or more of its committees. The Task Force believes that such a practice generally would not be desirable. Apart from the cost, the division of management and the board of directors into two separately counseled factions may result in less open communication, less constructive collaboration ... and, ultimately, less effective oversight by the board of directors. The Task Force recognizes . . that there are situations in which separate counsel ... may be necessary or desirable..$^{50}$

It would be too strong to say that the Final Report thus takes away in this footnote what had been proposed in the text. It is clearly contemplated, however, that independent directors under the SOX regime, particularly those on the Audit, Compensation, and Governance committees, can effectively discharge their new, heavy, and legally ambiguous responsibilities while being counseled only by the company's general counsel and members of the law department reporting to general counsel..$^{51}$

One can understand why the Task Force would include the reservation presented in footnote 54. The transition from the old "teamwork" regime to the new SOX regime has been sudden and unanticipated. The bar was not prepared for it: The ABA Ethics2000 Commission had not recommended changes that would readjust the balance in Rule 1.13 between "teamwork" and "disruption," and the Commission's recommendations for Rule 1.6 concerning "whistle-blowing" against financial fraud had been rejected by the House of Delegates. In hearings

49. Final Report, supra note 43, at 24.

50. Id. at 24 n. 54 .

51. Id. at 48. This makes the point about the importance of clients being able to engage in full and frank communications with their lawyers. This goal has already been complicated when the client is an organization, because there is no expectation of confidentiality vis a vis other corporate actors when a corporate actor consults with corporate counsel. That said, the underlying point has strength and provides guidance for structuring the governance structure to promote full and frank communication as a practical matter, even if the protections (and inducements to full and frank disclosures) of the attorney client privilege do not apply. One advantage of the IDC is that it has the practical effect of assisting in the full and frank communication by the independent directors, communications that they may feel uncomfortable having with the GC. 
addressed to its Preliminary Report, the Task Force was confronted by the passionate rhetoric of the American College of Trial Lawyers, denouncing any change in the "core values" of confidentiality and loyalty to client. ${ }^{52}$ The ABA House of Delegates has since adopted the changes to Rules 1.6 and 1.13 recommended by the Cheek Report. ${ }^{53}$ The change in Rule 1.6 is formally more substantial, but that in Rule 1.13, calling for more positive action by counsel, probably is more significant as a practical matter.

One can of course understand that independent directors could find themselves and their counsel falling into "two separately counseled factions," as said in footnote $54 .{ }^{54}$ But that misfortune is not inevitable, nor, in our opinion, even probable. There are many very good lawyers who have the diplomatic skills along with technical competence quite sufficient to provide tough but polite and constructive counsel to a board committee committed to the welfare of the company. Indeed, some versions of corporate management philosophy call for decision by "confrontation," and regard that as a positive form of "teamwork." 55 In all probability, a company reaching the stage of "separately counseled factions" would have had previous conflicts that, under the SOX legal regime, would have required resignation of someone, either in management, or on the board, or in corporate counsel's office.

The Cheek Report, itself, in grappling with the new duties that result from SOX, agrees with the importance of having the independent directors meet regularly outside the presence of "any senior executive officer," a requirement that was also part of the NYSE listing rule reforms. As soon as this step is taken, the question of an IDC arises sharply. Who will attend the meeting from which senior management is excluded? Will a lawyer be present and, if so, who? In general, one would think, the inside general counsel of a firm should be considered a "senior executive officer." If so, he cannot attend. If the general counsel is disqualified for this reason, it is hardly in the spirit of the reforms for a lawyer who works under the disqualified general counsel to advise the independent directors. Thus, either the meeting has to be held without a lawyer being present (clearly a bad idea), or the independent directors will need an IDC.

Concerning this last point, perhaps the Task Force, thoughtful as its Report certainly is, has not taken full account of the new roles and new responsibilities that result from SOX.

\section{New Roles, New Responsibilities}

The Cheek Report is largely focused on preventing violations of law. That focus-understandable given the long debates over the model rules-gives less

52. The stance taken by the College brings to mind the observation made by Talleyrand about the Bourbons of the Old Regime in France: "They have learned nothing, and they have forgotten nothing." The New Dictionary of Cultural Literacy (E.D. Hirsch, Jr., et al. ed., Houghton Mifflin Co. 2002), available at http://www.bartleby.com/59/10/bourbons.html.

53. See Final Report, supra note 43, at 41-61.

54. Id. at 24 n. 54 .

55. This approach is most prominently associated with Jack Welch, former CEO of General Electric. See Robert Slater, Jack Welch and the GE Way (1999). 
weight to the extent to which SOX seeks to restructure decision-making within the corporation. When the IDC emerges, counsel will play as large a role in implementing this new governance structure as it will in preventing violations of the law by the executive group. The general counsel's relationship with the management team is precisely what gets in the way of the general counsel (GC") guiding the independent directors through their governance obligations. This is so whether or not one accepts the premise of the Task Force that, in the rare instance in which law breaking by one of the management team is involved, the GC can effectively undertake to act.

\section{New Ways to Discharge Old Responsibilities}

Once an IDC is in place and is providing on-going guidance to the independent directors, one would expect that the IDC will take a lead role on those matters that currently require a special committee. Thus, we expect the IDC to change the process by which a board can take control of derivative litigation against senior management. While formerly it may have been necessary to hire new directors to staff a special litigation committee, and to hire new counsel to advise the committee, now it may be possible - if the directors are sufficiently independent- to delegate the decision whether to sue to the outside directors as a group, as advised by the IDC.

Similarly, in parent-subsidiary mergers, the IDC, if present, may play a similar role. The application of SOX and the other reforms to transactions involving controlled subsidiaries is complex. The NYSE Proposed Rules, for example, exempt controlled subsidiaries (defined as "a company of which more than fifty percent of the voting power is held by an individual, a group or another company") from a number of key requirements: a majority of independent directors; a Nominating/Corporate Governance Committee composed entirely of independent directors; and a Compensation Committee composed entirely of independent directors. ${ }^{56}$ Such companies are still subject to the Audit Committee requirements. One can certainly imagine a situation in which an Audit Committee, advised by its IDC, will play the role currently played by a special committee in a parentsubsidiary merger.

Finally, in the context of an internal investigation, one can again expect that the IDC, already carrying the responsibility of advising the Audit Committee on its investigations, would be well positioned to advise the Audit Committee or another committee of the board concerning a special investigation.

In all of these situations, when the IDC is genuinely independent, the IDC can potentially do a better job than outside counsel hired just for the engagement. The IDC will be more familiar with the company and will have already established a relationship with the independent directors.

56. NYSE Listed Company Manual, supra note $21, \S 303 \mathrm{~A}$. 


\section{A New Player in Control Transactions?}

As discussed earlier, the role of counsel to the special committee of independent directors is already familiar in the management buyout and parent-subsidiary merger transactional contexts. In both situations, the special committee takes center stage in representing the interests of the public shareholders. Counsel to the special committee, as we have seen, plays a crucial role in guiding the independent directors through their responsibilities. One interesting unresolved issue under Delaware law is how aggressive the special committee can be in pursuing the interests of the public shareholders. Can it, for example, adopt a poison pill to block a parent company tender offer for the minority shares to be followed by a short form merger, thereby avoiding Weinberger ${ }^{57}$ "entire fairness" scrutiny ${ }^{38}$ If, in the face of such a defensive tactic by the special committee, the parent company replaces the directors with new directors who redeem the poison pill, what level of scrutiny will the Delaware courts apply to that action?

Now imagine that we become accustomed to the presence of an IDC. What implications does this have for Delaware merger and acquisition (M\&A) jurisprudence? One possibility is that a defensive tactic adopted by the independent directors advised by the IDC will be entitled to greater deference than a defensive measure adopted by the board as a whole represented by corporate counsel. The Delaware courts already give substantially greater deference to decisions by independent boards than inside boards. ${ }^{59}$

It would be but a short step beyond existing jurisprudence for the Delaware courts to grant similar or greater deference to decisions made by independent directors advised by the IDC. Just as Delaware jurisprudence has piggy-backed on the emergence of independent directors-relying on them when they act independently and encouraging their emergence by granting their decisions deference-so too could Delaware piggy back on the emergence of the IDC. ${ }^{60}$

\section{In CEO Retention or Dismissal}

The 1992 dismissal of General Motors (GM) CEO Robert Stempel, under pressure from outside directors, marked a watershed in American corporate governance. GM's outside directors, concerned with the direction of the company, retained Ira Millstein as counsel on an ad hoc basis. Millstein tutored the outside directors on their obligations, and guided them through a process that ultimately

57. Weinberger v. UOP, Inc., 457 A.2d 701 (Del. 1983).

58. Jeff Gordon \& Ron Gilson, Controlling Controlling Shareholders, 152 U. PA. L. REV. 785 (2003).

59. See, e.g., Unocal Corp. v. Mesa Petroleum Co., 493 A.2d 946, 955 (Del. 1985) ("In the face of this inherent conflict directors must show that they had reasonable grounds for believing that a danger to corporate policy and effectiveness existed because of another person's stock ownership. [Cheff $v$. Mathes, 199 A.2d 548, 554-55 (Del. 1964)l. However, they satisfy that burden 'by showing good faith and reasonable investigation. ...' [Cheff, 199 A.2d at 555]. Furthermore, such proof is materially enhanced, as here, by the approval of a board comprised of a majority of outside independent directors who have acted in accordance with the foregoing standards.") (emphasis added).

60 . Indeed, the possibility of this happening will be obvious to CEOs and corporate counsel, and could well lead to significant opposition. 
led to the humiliating dismissal of Stempel. ${ }^{61}$ The GM boardroom uprising is an example of what organized and well counseled outside directors can do, if they choose to. It is an experience that has not been forgotten. CEOs will recognize the possibility that a standing IDC, providing continuing counseling to the independent directors, will result in better organized independent directors, and less secure CEOs. One can therefore predict opposition to the appointment of an IDC.

\section{SOME OTHER (NON?) ISSUES}

In this section, we address some of the objections that will be raised.

\section{Who Speaks for the Corporation?}

One objection to the IDC is that it will create confusion in the boardroom. With the multiplication of corporate counsel, some might argue, it will be unclear "who speaks for the corporation."

The quick response to this objection is that it is misconceived. Basic corporate law makes clear that it is the board of directors which speaks for the corporation, not corporate counsel, IDC, outside directors, nor, for that matter, the CEO.

The more complete answer is that who, in fact, speaks for the corporation will depend, as it always has, on the context. Sometimes, the general counsel speaks for the corporation when, for example, the issue is the conduct of litigation with some third party. Other times, the CEO speaks for the corporation when, for example, the corporation is called to testify in front of a congressional committee. Sometimes, the full board of directors speaks for the corporation, when, for example, the issue is the incurring of large indebtedness. Sometimes, only the board and the shareholders together can speak for the corporation, when, for example, the issue is whether to merge with another firm.

\section{Confidentiality}

A persisting problem in any client-lawyer relationship with an organization is that of maintaining client confidences in an appropriate way. Confidences about a client must be maintained in confidence, not only as a matter of immediate duty but also because disclosure to outsiders can result in embarrassment as a practical matter and loss of the right of confidentiality as a legal matter. At the same time, confidential information must be employed in carrying out the representation. The necessary transmissions may be within the organization or to outsiders.

With an organization client, it is the organization that is the client, not any specific person. As stated in Model Rules 1.13(a), "A lawyer employed or retained by an organization represents the organization ..."62 This proposition derives 
from corporation law itself. ${ }^{63}$ Thus, not even the CEO unqualifiedly "personifies" the corporation in relationships with legal counsel. ${ }^{64}$ On the contrary, identifying the relevant participants in the confidential relationship is a continuing problem in the client-lawyer relationship with a corporation or other organization.

As a general proposition and under ordinary circumstances, the practical rule is simply to treat all members of the enterprise as within the circle of confidentiality. Certainly, there is no occasion for going outside that circle unless serious legal harm to the company is threatened by some course of action or inaction by corporate personnel. If that threat involves financial issues, SOX may. require counsel to go "up the ladder" within the corporation. The Rules of Professional Conduct would require similar response by the lawyer whether or not the issue was financial (e.g., environmental regulation or employment obligations) ${ }^{65}$ But going up the ladder within the corporation does not breach confidentiality. Every higher official to whom the lawyer could resort would also be within the corporation's confidentiality circle. The circle would include the group of inside directors having the special authority and responsibility that is formalized in SOX.

A sensitive choice of pathway could be involved however. Suppose the company's inside general counsel discovers that the chief financial officer has concealed accounting problems that should be corrected. Presumably, the first response is to turn to the CFO, asking rectification of the accounts. The CFO replies that the issue has been reviewed and approved by the CEO. Does the general counsel now go to the CEO, as the next rung on the corporate ladder, or to the board as a whole, in accordance with the normal corporate hierarchy above the $\mathrm{CEO}$ ? Or to the independent directors, in accordance with the mandate apparently prescribed by SOX? Suppose that the general counsel suspects that the CEO was involved in the concealment in the first place, and that the two officers may further manipulate the accounts in order to cover up? ${ }^{66}$

None of these pathways would involve disclosure of confidences outside the corporate entity, because all the parties involved are constituents of the corporation and not outsiders. Moreover, each one of them could consult independent counsel, on the premise that a fiduciary's consultation with his or her own lawyer is not a breach of confidence on the part of the fiduciary. That would apply also to the insider directors if they already had or then retained their own special counsel. If the matter is resolved quietly and peacefully, no outside disclosure would be necessary or proper.

Suppose the matter is not resolved quietly, however. Rather, the CEO (advised by independent counsel he has retained) insists that the accounts remain as reported, whereas the independent directors, advised by their special counsel, conclude that the accounts should be restated. Can the independent directors take action requiring disclosure to outsiders, for example, the SEC?

63. See, e.g., Commodity Futures Trading Comm'n v. Weinraub, 471 U.S. 343 (1985).

64. See, e.g., Meehan v. Hopps, 301 P.2d 10 (Cal. Dist. Ct. App. 1956).

65. See Model Rules of PROF'L Conduct R. 1.13(b) (2000).

66. See generally FDIC v. O'Melveny \& Meyers, 969 F2d 744 (9th Cir. 1992). 
It seems to us that the logic of corporate law and of SOX requires the conclusion that the independent directors can "go public" to the extent they reasonably deem necessary to carry out their responsibilities to the company. The hypothetical sequence of events has reposed on the independent directors' responsibility to act in the best interest of the company and, in the hypothesis, they have concluded that interdiction is necessary. That could have been the scenario in WorldCom, for example. If the independent directors so concluded, their special counsel would properly advise them that they could make outside disclosures as necessary. And their special counsel would thereby have acted consistent with his professional responsibility. As stated in ABA Model Rule 1.6(a)

A lawyer shall not reveal information relating to the representation of a client unless ... the disclosure is impliedly authorized in order to carry out the representation ...

Perhaps needless to say, it would not be a happy day for anyone concerned. ${ }^{67}$

\section{Attorney Client Privilege}

Distinct from the lawyer's duty of confidentiality is the attorney client privilege. The duty of confidentiality imposes a (qualified) burden of secrecy on the lawyer concerning disclosures of "information relating to the representation," in the terminology of Rule $1.6^{68}$ The duty thus covers information whatever its source and prohibits disclosure wherever and to whomever, in court or outside. The attorney client privilege has a lesser scope and is differently directed. The privilege applies only to communications from the client in seeking legal assistance and responses from the lawyer in connection thereto. It is a rule addressed to inquiring persons, whether courts or other parties, and directs that they not seek the protected matter. The privilege is that of the client but ordinarily is invoked by the attorney on behalf of the client. ${ }^{69}$

The attorney client privilege generally applies to communications between corporate personnel and legal counsel. ${ }^{70}$ The typical context for its application is a legal dispute between the corporation and a third party. The privilege can also apply in disputes between "constituents" of the company, for example, between an officer or former officer and the company or, in the derivative suit context, between shareholders and the company management. In the latter context, however, there is often difficulty and confusion as to those for and against whom the privilege may be asserted. The problem is often referred to as that in Garner v. Wolfinbarger, ${ }^{71}$ the 1970 Fifth Circuit case in which it was addressed.

The issue, stated in general terms, concerns the circumstances in which the attorney client privilege, normally operative for the corporation against third par-

67. Model Rules of Prof'l Conduct R. 1.6(a) (2000).

68. Id. at 1.6 .

69. See Restatement (Third) of the Law Governing Lawyers, $\$ \S 68,73$ (2000).

70. See Upjohn Co. v. United States, 449 U.S. 383 (1981).

71. 430 F.2d 1093 (5th Cir. 1970). 
ties, should not protect one corporate constituent against another. In Garner, the dispute was between plaintiffs in a shareholder derivative action and incumbent management. The Garner exception has since been applied in a variety of circumstances. Application of Garner can readily be imagined in a dispute between independent directors and incumbent or former management. Unfortunately, formulation of the concept was and is in very ambiguous terms. As set forth in the Restatement of the Law Governing Lawyers, it is as follows:

In a proceeding involving a dispute between an organizational client and shareholders, members, or other constituents ... the attorney-client privilege of the organization may be withheld ... if . . . the need of the requesting party ... is sufficiently compelling and the threat to confidentiality sufficiently confined to justify setting the privilege aside. ${ }^{72}$

We venture to say that in a dispute in which the independent directors are seeking to compel information from any other constituent of the corporationtop management or even the majority of the board-in a subject within the scope of SOX, the Garner principle will "justify setting the privilege aside." The independent directors in such a dispute would have the highest level of fiduciary responsibility and the public policy of SOX would most strongly militate in favor of disclosure. By the same token, however, the independent directors would probably have the strongest case for privilege for their communications with special counsel in their inquiry and deliberations concerning that subject matter. In any event, the disclosure could be limited to the immediate controversy through imposition of a protective order by the court in which the dispute is pending.

Predicting application of the rule of privilege on the Garner exception is necessarily somewhat speculative, however. Moreover, the problem could arise among officials who, at the time of the underlying transaction, had a close and trusting relationship with each other. These conditions signify that the lawyer's duty to define the professional relationship is especially important. That duty is expressed in Model Rule 1.13(f) as follows:

In dealing with an organization's directors, officers, employees, members, shareholders or other constituents, a lawyer shall explain the identity of the client when the lawyer knows or reasonably should know that the organization's interests are adverse to those of the constituents with whom the lawyer is dealing. ${ }^{73}$

This provision sometimes is colloquially called the "corporate Miranda warning," harking to the warning that police must give to criminal suspects. That description indicates the unpleasantness of the occasion on which the message must be delivered and the anxiety and perhaps anger with which it would be received. Nevertheless, the message must be transmitted in the interest of fairness to the individuals involved, of protection of the corporate interest, and of the

72. Restatement (Third) OF the LaW Governing LaWyers, § 85 (2000).

73. Id. 
lawyer's own legal responsibility. Failure to give the warning could result in loss of privilege for the corporation, accrual of privilege to an individual who supposes that he was individually represented, and conflict of interest for the lawyer on the basis that he had multiple clients.

Where the independent directors have special counsel, the warning requirement will apply to them. A separate warning may be required on the part of the regular general counsel as well. The whole exchange no doubt will appear as legal persiflage to some of the directors, but it ought to be done-and confirmed in writing.

\section{Who's the Client?}

If an IDC is retained, a subsidiary problem is the designation of the client. There are at least three possibilities: the company; the committee; or the members of the committee. Each alternative has some advantages and disadvantages. The important thing, however, will be the terms of engagement. We recommend that the IDC be designated "special counsel," in order to signal clearly that the scope of authority and responsibility is limited, and that an engagement letter address various specific issues, as suggested below. In the course of experience, one or more standard form engagement letters will no doubt evolve.

\section{The Company}

Special counsel could be engaged by the company, and assigned to assist the committee. This designation would signify that the lawyer's duty of loyalty and ultimate responsibility run to the company as distinct from the committee as such or its members. It would imply that communications with the committee were not confidential as against "the company." That could mean that at least the board as a whole, and possibly top management, could insist on disclosure of communications between the committee and special counsel. It would imply that normally the deliberations and decisions of the committee would be fully disclosed to the board and to management. It would also mean that, if the committee and management came into conflict, the lawyer could not take a position adverse to the company (in the absence of a proper advance waiver by the company).

\section{The Committee}

Special counsel could be engaged by the committee, although compensated by the company. The committee would speak to and work with special counsel through its governing structure, particularly through its chair. The committee's "decision rule" would be majority vote if there were internal differences of opinion. Communications would be confidential as against the company and the lawyer's ultimate duty of loyalty would run to the committee. The company would be a third party, but one with a "common interest." Under the common interest concept, the confidentiality of communications would be protected as against other third parties. Special counsel could continue to represent the committee even in 
litigation in which its position was adverse to the company acting through top management or the board as a whole.

\section{Members of the Committee}

Special counsel could be engaged by members of the committee, as distinct from the committee as such. The principal difference between this structure and that described above would be that counsel would have to work with all committee members equally rather than through the committee's chair. If the committee itself was divided in judgment or course of action, special counsel could confront an additional basis of conflict and might be disabled from continuing in any capacity.

Among these alternatives, in our view the best is designation of the IDC as representing the committee. We believe the "common interest" concept provides protection as against outside parties while preserving the committee's autonomy. ${ }^{74}$ It would be highly advisable, however, to address the issues suggested above explicitly in the engagement letter:

- The internal decision rule for the committee;

- Identification of the persons by and through whom the committee communicates with counsel;

- The authority to discharge special counsel or modify the terms of engagement;

- The normal terms of confidentiality and primary loyalty, and exceptions or qualifications thereto, if any;

- Adjustments in the event of conflict between the committee and the board or top management.

\section{Conclusion}

The Sarbanes-Oxley Act imposes a new federal regime on top of traditional state corporation law. In imposing a more judgmental model of monitoring public companies, SOX changes the duties of corporate officers and directors and legal counsel compared with those that have long been established by state corporate law and state professional regulations. ${ }^{75}$ Moreover, in many contexts SOX makes these duties a matter of federal law with SEC enforcement. Neither corporate officials nor lawyers will want to "mess with the feds."

What will be the costs and benefits of an emergence of an IDC? The immediate costs will be some increase in legal fees over and above the costs of complying with SOX. While there will be some cost-shifting (work that would have been done by the corporate general counsel will now be done by the IDC), it would

74. See Restatement (ThiRd) OF THe LaW Governing LaWyers $\$ 76$ (2000).

75. The counterattack by the Washington State Bar seems to us to be based on wholly mistaken assumptions. As a matter of state law everywhere, including Washington State, corporate counsel represents the corporation, not the officers or directors. Taking a matter "up the ladder" to the board, or to the insider directors, is an intramural recourse, not a breach of the duty of confidentiality. 
be naive to assume that adding an independent lawyer will not increase total legal costs. If nothing else, the IDC will need to demonstrate the wisdom of the committee's decision to retain him or her. On the benefits side, there may be some savings if the IDC serves as special counsel for the special litigation committee evaluating a derivative suit, or the special committee conducting an internal investigation or negotiating a parent-subsidiary merger. But this savings is also likely to be small because, in at least a significant proportion of these situations, the IDC may not be considered sufficiently independent to represent the special committee.

The real costs and benefits derive from SOX itself. Will SOX succeed in forcing firms to adopt a judgmental monitoring model of board governance? If so, will the benefits of a less collegial model of board governance outweigh the costs? That is the key question posed by SOX, and well beyond the scope of this article. ${ }^{76}$

\section{The Future OF BoARd GovernanCE}

The Delaware general corporation law tells us that the "business and affairs of every corporation ... shall be managed by or under the direction of a board of directors. ${ }^{77}$ But how board governance in fact occurs is, and has always been, an evolving process in which business practices, market pressures and changing legal requirements meet. The Sarbanes-Oxley Act, enacted against the backdrop of corporate scandals, was designed to change board governance. Whatever one's views of its virtues, Congress quite clearly sought to force firms to adopt a different model of corporate governance in which independent directors will intrusively monitor managers.

An IDC is a critical player in the compliance with SOX's mandates and in the implementation and realization of this model. We predict that the new requirements will be the final push that will lead to the emergence of counsel for the independent directors. Whether that will be a good thing for corporate governance, corporate responsibility, or corporate profitability remains to be seen.

76. For a skeptical view, see Roberta Romano, "Sarbanes-Oxley Act and the Making of Quack Corporate Governance," (working paper).

77. Del. Code ANN. tit 8, §14l(a) (Supp. 2003). 